\title{
PENGARUH KESIAPAN BELAJAR TERHADAP HASIL BELAJAR MATEMATIKA SISWA KELAS IV DI SDN SE-KECAMATAN PURING
}

\author{
Fityan Ferry Sukma $\mathbf{P}^{1}$, Muhamad Chamdani ${ }^{2}$, Tri Saptuti Susiani ${ }^{3}$ \\ Universitas Sebelas Maret \\ fityanferry@student.uns.ac.id
}

\section{Article History}

accepted 1/11/2021

approved 1/12/2021

published 31/12/2021

\begin{abstract}
The study aimed to determine positive effect between readiness and mathematics learning outcomes to fourth grade students of public elementary schools in Puring Sub-district and to measure the contribution of readiness on mathematics learning outcomes to fourth grade students of public elementary schools in Puring Sub-district. The research was correlational quantitative method. Sampling method was cluster random sampling technique and calculated by Slavin and Taro Yamane formula. Prerequisite test on this study is fulfilled, there are data distribution is normal, data is linear and data has been changed become interval data. The correlation test of readiness and mathematics learning outcomes showed Sig value was 0.000 and correlation coefficient was 0.534 . The value effective contribute on student's mathematics learning outcomes is $28.5 \%$. It concludes that there is positive effect between readiness and mathematics learning outcomes to fourth grade students of public elementary schools in Puring Sub-district.
\end{abstract}

Keywords: readiness, learning outcome, mathematics

\begin{abstract}
Abstrak
Penelitian ini bertujuan untuk membuktikan adanya pengaruh positif antara kesiapan belajar dan hasil belajar matematika siswa kelas IV di SDN se-Kecamatan Puring dan besarnya sumbangan efektif kesiapan belajar terhadap hasil belajar matematika siswa kelas IV di SDN se-Kecamatan Puring. Penelitian ini merupakan penelitian kuantitatif dengan metode korelasi. Pengambilan sampel dihitung menggunakan rumus Slavin dan Taro Yamane dan diambil secara acak dengan teknik cluster sampling. Uji prasyarat data pada penelitian ini telah terpenuhi yaitu data berdistribusi normal, data linier, serta telah ditransformasi menjadi data interval. Hasil uji korelasi kesiapan belajar dan hasil belajar matematika menunjukkan bahwa nilai Sig. sebesar 0,000 dan nilai koefisien korelasi sebesar 0,534. Besar sumbangan efektif kesiapan belajar terhadap hasil belajar matematika yaitu $28,5 \%$. Berdasarkan analisis dan pembahasan hasil penelitian dapat disimpulkan bahwa terdapat pengaruh positif antara kesiapan belajar dan hasil belajar matematika siswa kelas IV di SDN se-Kecamatan Puring.
\end{abstract}

Kata kunci: kesiapan belajar, hasil belajar, matematika 


\section{PENDAHULUAN}

Pendidikan adalah sebuah cara meningkatkan kualitas sumber daya manusia. Pendidikan merupakan suatu proses yang panjang serta berkelanjutan. Peserta didik akan dikembangkan untuk selanjutnya dia akan menjadi manusia yang akan berguna untuk orang lain maupun untuk dirinya sendiri. Pemerintah juga menyebutkan dalam UU Sisdiknas No. 20 tahun 2003:

"Pendidikan adalah usaha sadar dan terencana untuk mewujudkan suasana belajar dan proses pembelajaran agar peserta didik secara aktif mengembangkan potensi dirinya untuk memiliki kekuatan spiritual keagamaan, pengendalian diri, kepribadian, kecerdasan, akhlak mulia, serta keterampilan yang diperlukan dirinya, masyarakat, bangsa dan negara."

Menurut Slameto (Bujuri dkk, 2015: 1) pada seluruh proses pendidikan di sekolah, kegiatan belajar adalah kegiatan paling pokok. Oleh karena itu keberhasilan pencapaian tujuan pendidikan juga banyak bergantung pada bagaimana proses pembelajaran yang siswa alami sebagai anak didik. Pada era sekarang ini siswa diharapkan untuk aktif dan mandiri, tidak hanya mengandalkan guru atau orang lain sebagai pemberi materi, terlihat dari buku yang diberikan pemerintah yang hanya memuat materi tidak secara spesifik sehingga menuntut kreativitas siswa di samping guru yang harus berkreasi juga.

Proses belajar adalah aktivitas psikis mengenai bahan belajar. Aktivitas belajar yang siswa lakukan merupakan suatu proses dalam mempelajari sesuatu, karena belajar merupakan kegiatan pokok. Selain itu, belajar merupakan kunci dalam pembentukan kompetensi peserta didik, karena peserta didik akan dapat belajar apabila sudah ada kesiapan dari dalam dirinya yang berkaitan dengan proses belajar (Sinta, 2017: 12). Menurut Pakasi (Sobur, 2013: 236) dalam sifat proses belajar terdapat sifat yaitu kesiapan pada anak yang berupa keadaan rohaniah (emosional, sosial dan intelektual) diperlukan dalam belajar. Anak seharusnya merasa sanggup dan siap untuk menerima tugas perkembangan ataupun pelajaran yang baru. Kesiapan ini adalah syarat penting untuk kelancaran jalannya proses belajar. Belajar adalah aktivitas yang akan membawa menjadi berpikir tingkat abstrak dari berpikir tingkat konkret. Anak harus dapat berpikir abstrak, karena apabila ia terus menetap pada tingkat berpikir konkret, proses berpikir anak akan menjadi terhambat.

Hubungannya dengan matematika yang merupakan ilmu yang abstrak dan deduktif, siswa SD yang ada pada usia 7 tahun sampai 12 tahun masih dalam tahap operasional konkret yang belum bisa berpikir formal sehingga siswa merasa bahwa matematika adalah pelajaran yang sulit yang menyebabkan mereka tidak suka pada pelajaran matematika. Hal ini sesuai dengan pendapat Marti (Sundayana, 2015: 3) yang menyatakan bahwa objek matematika yang sifatnya abstrak adalah kesulitan tersendiri yang harus dihadapi dalam mempelajari matematika oleh siswa. Selanjutnya dalam modul dari UPI, sifat-sifat belajar matematika salah satunya adalah matematika memerlukan kesiapan anak didik, artinya bahwa anak sudah matang dan sudah menguasai apa yang diperlukan. Jika belum siap maka anak tidak boleh dipaksa untuk belajar matematika karena anak itu malas belajar dan merasa tidak mampu belajar. Selain itu dalam belajar matematika untuk mendapatkan keterampilan matematika diperlukan latihan secara terus menerus atau berkali-kali, oleh karena itu anak harus secara teratur melakukan latihan baik tertulis maupun lisan.

Pada kurikulum ini, hasil belajar masih menjadi indikator tingkat keberhasilan atau pemahaman siswa dalam suatu materi. Untuk itu hasil belajar adalah hal penting dari siswa untuk ditingkatkan. Selanjutnya, Susanto (2016: 5) menyatakan bahwa hasil belajar adalah segala perubahan yang terjadi pada diri siswa, yang mengenai aspek psikomotor, kognitif, dan afektif sebagai suatu hasil dari kegiatan belajar. Dalam jurnalnya, Syahputra (2016: 86) menyimpulkan bahwa terdapat pengaruh positif kesiapan belajar terhadap prestasi belajar matematika berdasarkan indeks determinasi 
sebesar 0,1 yang berarti kesiapan belajar memengaruhi sebanyak $10 \%$. Sejalan dengan pendapat Syahputra, Fitriana dkk. (2013: 45) menyatakan bahwa Rho hitung > Rhokritik sehingga ( $\mathrm{Ho}$ ) ditolak dan hipotesis kerja diterima, berarti ada hubungan antara kesiapan belajar dan hasil belajar dengan nilai Rho hitung 0,746 pada kelas interval $0,60-0,799$ yang berarti terdapat korelasi yang kuat antara variabel $X$ dan variabel $Y$.

Tetapi pada masa pandemi ini kesiapan belajar peserta didik rendah. Hal tersebut dapat diketahui melalui pernyataan para guru. Kesimpulan yang dapat diambil dari pernyataan guru-guru tersebut adalah kesiapan belajar peserta didik kurang karena hal-hal sebagai berikut. Pertama, tatap muka tidak dilaksanakan yang membuat peserta didik menjadi merasa tidak diawasi, orang tua mereka yang umumnya bekerja di sawah sejak pagi kurang dapat mengawasi mereka. Kedua, kurangnya pengetahuan teknologi yang membuat orang tua ataupun peserta didik belum mampu menggunakan teknologi seperti contohnya smartphone dengan baik untuk membantu proses pembelajaran. Ketiga, penyimpangan penggunaan data yang membuat kuota yang disubsidi dari pemerintah habis begitu cepat, hal ini disebabkan karena kurangnya pengawasan orang tua juga sehingga membuat peserta didik menggunakan kuota tidak untuk belajar. Keempat, penyampaian informasi yang kurang sempurna yang membuat peserta didik tidak tersampaikan ilmunya dari guru secara maksimal karena kurangnya tatap muka. Kelima, keterbatasan sarana dan prasarana yang menyebabkan beberapa peserta didik tidak mempunyai smartphone sehingga pemberian informasi dan komunikasi dapat terhambat. Akibat hal tersebut mereka para guru merasa khawatir akan kurangnya hasil angket dan tes.

Tujuan dari penelitian ini adalah untuk membuktikan adanya pengaruh positif kesiapan belajar terhadap hasil belajar matematika dan menjelaskan besar sumbangan kesiapan belajar terhadap hasil belajar matematika.

\section{METODE}

Penelitian ini merupakan penelitian kuantitatif dengan metode korelasi. Variabel pada penelitian ini terdiri dari variabel bebas $(X)$ yaitu kesiapan belajar dan variabel terikat $(Y)$ yaitu hasil belajar matematika. Populasi dari penelitian ini adalah seluruh siswa kelas IV SDN se-Kecamatan Puring Kabupaten Kebumen sebanyak 966 siswa dengan sampel sebanyak 220 siswa. Teknik sampling yang digunakan yaitu teknik probability sampling jenis cluster sampling.

Teknik yang digunakan dalam mengumpulkan data adalah angket dan tes. Angket digunakan untuk mengumpulkan data penelitian kesiapan belajar. Angket kesiapan belajar berupa angket dengan jenis skala likert yang berbentuk checklist. Pembuatan instrumen kesiapan belajar dikembangkan dari 10 indikator. Indikator tersebut yaitu perhatian, motivasi belajar, perkembangan kematangan, kondisi fisik, kondisi mental, kondisi emosional, kebutuhan, motif dan tujuan, keterampilan, dan pengetahuan dan pengertian lain yang telah dipelajari. Tes digunakan untuk mengumpulkan data hasil belajar matematika. Tes yang digunakan dalam penelitian ini berupa soal pilihan ganda materi matematika kelas IV semester 1 dan 2 sebanyak 37 soal.

Uji validitas pada penelitian ini menggunakan analisis korelasi Product Moment Pearson dan pada uji reliabilitas menggunakan Cronbach Alpha. Berdasarkan hasil uji validitas, angket kesiapan belajar yang terdiri dari 50 butir angket terdapat 31 butir angket yang valid, instrumen tes matematika yang terdiri dari 50 soal terdapat 37 soal yang valid. Uji reliabilitas angket sikap ilmiah menunjukkan nilai 0,864 dan tes hasil belajar matematika 0,890 sehingga kedua instrumen tersebut dapat dikategorikan reliabel sangat tinggi.

Uji prasyarat data penelitian ini yaitu uji normalitas data, uji linieritas data, serta metode suksesif interval. Setelah semua uji prasyarat terpenuhi, data tersebut 
kemudian dianalisis menggunakan teknik korelasi Pearson Product Moment dengan bantuan aplikasi SPSS. Hipotesis untuk analisis korelasi penelitian ini yaitu:

$\mathrm{H}_{\mathrm{o}}: \rho=0$ tidak terdapat hubungan antara kesiapan belajar dan hasil belajar matematika

$\mathrm{H}_{\mathrm{a}}: \rho>0$ terdapat hubungan antara kesiapan belajar dan hasil belajar matematika

Kriteria pengujian berdasarkan signifikansi (dengan $\alpha=5 \%$ ):

Jika signifikansi $\geq 0,05$, maka terima $\mathrm{H}_{\circ}$

Jika signifikansi $<0,05$, maka tolak $\mathrm{H}_{\mathrm{o}}$.

Selain menganalisis korelasi, penelitian ini juga menganalisis sumbangan efektif. Analisis sumbangan efektif menggunakan rumus sebagai berikut:

$S E=(S R) \times\left(R^{2}\right)$

Keterangan :

$\mathrm{SE}$ = sumbangan efektif

$\mathrm{R}^{2} \quad=$ koefisien determinasi

$\mathrm{SR}$ = sumbangan relatif

HASIL DAN PEMBAHASAN

Penelitian ini dilakukan dengan memberikan angket kesiapan belajar dan soal tes matematika kepada siswa kelas IV di SD yang menjadi sampel penelitian. Berdasarkan hasil analisis data, dapat dideskripsikan hasil belajar matematika dan kesiapan belajar serta korelasi antara kesiapan belajar dan hasil belajar matematika. Rata-rata skor hasil belajar matematika adalah 24,5591 dari skor maksimal 37. Ratarata skor kesiapan belajar adalah 54,7985 dari skor maksimal 82,92. Rata-rata pada masing-masing indikator kesiapan belajar dapat dilihat pada gambar 1.

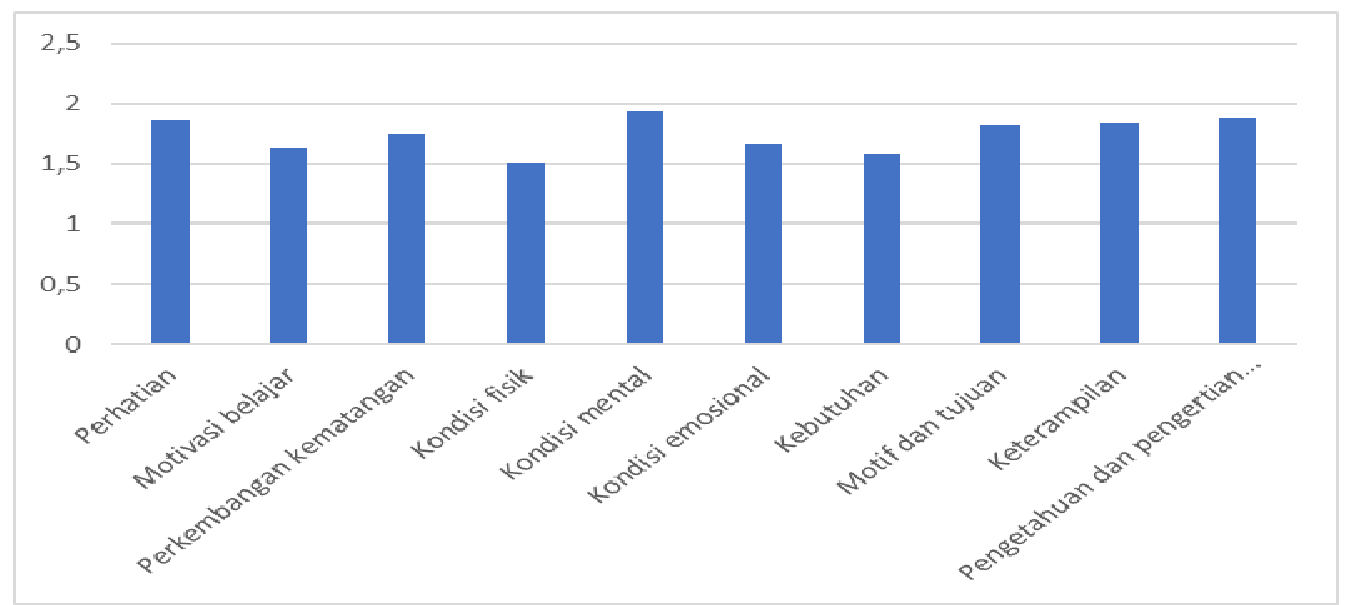

Gambar 1. Rata-rata Skor Indikator Kesiapan Belajar

Uji prasyarat data pada penelitian ini telah terpenuhi yaitu data berdistribusi normal, data linier, serta telah ditransformasi menjadi data interval. Uji normalitas dilakukan dengan menggunakan metode Kolmogorov-Smirnov yang menunjukkan nilai signifikansi sebesar 0,058 pada variabel $X$ dan nilai signifikansi sebesar 0,200 pada variabel $\mathrm{Y}$. Kedua variabel menunjukkan nilai $>0,05$ sehingga dapat disimpulkan kedua variabel tersebut berdistribusi normal. Uji linieritas menunjukkan nilai Sig. Deviation from Linearity sebesar 0,052 . Nilai signifikansi tersebut $>0,05$ sehingga dapat disimpulkan bahwa terdapat hubungan linier antara variabel $\mathrm{X}$ dan variabel $\mathrm{Y}$. 
Setelah uji prasyarat analisis data terpenuhi, selanjutnya dilakukan uji hipotesis berupa uji korelasi dan sumbangan efektif.

Uji korelasi digunakan untuk mengetahui hubungan antara kesiapan belajar dan hasil belajar matematika. Analisis korelasi yang digunakan yaitu analisis korelasi Pearson Product Moment menggunakan aplikasi SPSS. Hasil uji korelasi antara kesiapan belajar dan hasil belajar matematika ditampilkan pada tabel berikut ini.

Tabel 1. Hasil Uji Korelasi antara Kesiapan Belajar dan Hasil Belajar Matematika

\section{Correlations}

\begin{tabular}{llr|r} 
& & \multicolumn{2}{c}{$\begin{array}{c}\text { kesiapanbela } \\
\text { jar }\end{array}$} \\
\hline hasilbelajar & Pearson Correlation & 1 & \multicolumn{1}{c}{$534^{\star \star}$} \\
\cline { 2 - 4 } & Sig. (1-tailed) & &, 000 \\
\cline { 2 - 4 } & $\mathrm{N}$ & 220 & 220 \\
\hline \multirow{2}{*}{ kesiapanbelajar } & Pearson Correlation &, $534^{\star \star}$ & 1 \\
\cline { 2 - 4 } & Sig. (1-tailed) &, 000 & \\
\cline { 2 - 4 } & $\mathrm{N}$ & 220 & 220 \\
\hline
\end{tabular}

**. Correlation is significant at the 0.01 level (1-tailed).

Hipotesis pada penelitian ini yaitu terdapat pengaruh positif dan signifikan antara kesiapan belajar dengan hasil belajar matematika siswa kelas IV di SDN seKecamatan Puring. Hasil pengujian hipotesis menggunakan SPSS versi 26 menunjukkan bahwa nilai Sig. (1-tailed) yaitu 0,000. Nilai Sig. tersebut $<\alpha(0,05)$, artinya hipotesis pada penelitian ini dapat diterima. Hasil analisis koefisien korelasi antara variabel kesiapan belajar dan hasil belajar matematika yaitu 0,534. Berdasarkan pendapat Riduwan (2015: 138) koefisien korelasi 0,534 termasuk dalam kategori cukup.

Berdasarkan penelitian dan perhitungan yang telah dilakukan, dapat diketahui bahwa kesiapan belajar mempunyai hubungan positif dengan hasil belajar matematika. Oleh karena itu, dapat dikatakan bahwa semakin tinggi kesiapan belajar siswa, maka akan semakin tinggi pula hasil belajar matematika siswa. Begitu pula sebaliknya, semakin rendah kesiapan belajar siswa, maka akan semakin rendah hasil belajar matematika siswa. Hal ini sesuai dengan jurnal Syahputra (2016: 86) menyimpulkan bahwa terdapat pengaruh positif kesiapan belajar terhadap prestasi belajar matematika berdasarkan indeks determinasi sebesar 0,1 yang berarti kesiapan belajar memengaruhi sebanyak 10\%. Sejalan dengan pendapat Syahputra, Fitriana (2013: 45) menyatakan bahwa Rho hitung $>\mathrm{Rho}_{\text {kritik }}$ sehingga $(\mathrm{Ho})$ ditolak dan hipotesis kerja diterima, berarti ada hubungan antara kesiapan belajar dan hasil belajar dengan nilai Rho hitung 0,746 pada kelas interval 0,60-0,799 yang berarti terdapat korelasi yang kuat antara variabel $X$ dan variabel $Y$.

Selain membuktikan korelasi antara kesiapan belajar dan hasil belajar matematika siswa kelas IV, penelitian ini juga bertujuan untuk mengetahui besar sumbangan kesiapan belajar terhadap hasil belajar matematika siswa kelas IV. Hasil perhitungan sumbangan efektif pada variabel kesiapan belajar terhadap hasil belajar matematika didapatkan hasil sebesar $28,5 \%$, artinya kesiapan belajar siswa dapat berperan dalam meningkatkan hasil belajar matematika sebesar $28,5 \%$ dan sisanya sebesar $71,5 \%$ dipengaruhi oleh faktor lain diantaranya intelegensi, kelelahan, cara orang tua mendidik, relasi guru dengan murid, teman bergaul dan lain-lain. Hal ini 
sesuai dengan jurnal Syahputra dam Fitriana dkk. bahwa semakin tinggi kesiapan belajar maka hasil belajar matematika akan semakin tinggi juga.

\section{SIMPULAN}

Berdasarkan hasil penelitian mengenai pengaruh kesiapan belajar terhadap hasil belajar matematika siswa kelas IV se-Kecamatan Puring dapat ditarik kesimpulan bahwa: (1) kesiapan belajar memiliki pengaruh positif terhadap hasil belajar matematika siswa kelas IV di SDN se-Kecamatan Puring, dengan nilai rhitung $(0,534)$ $>$ rtabel $(0,138)$ yang berarti terdapat korelasi positif antara kesiapan belajar dan hasil belajar matematika. Koefisien korelasi pada penelitian ini bernilai positif artinya kenaikan pada skor kesiapan belajar akan diikuti kenaikan skor hasil belajar dan penurunan skor kesiapan belajar akan diikuti penurunan skor hasil belajar matematika, (2) sumbangan efektif kesiapan belajar terhadap hasil belajar matematika siswa kelas IV di SDN se-Kecamatan Puring adalah $28,5 \%$ dan sisanya $71,5 \%$ dipengaruhi oleh faktor lain diantaranya intelegensi, kelelahan, cara orang tua mendidik, relasi guru dengan murid, teman bergaul dan lain-lain.

Berdasarkan simpulan yang telah disebutkan, peneliti memberikan beberapa saran sebagai berikut: (1) guru hendaknya mempersiapkan kesiapan belajar siswa sebaik mungkin dengan cara menerapkan model, metode, teknik, pendekatan, teori dan strategi pembelajaran yang tepat, sehingga hasil belajar siswa dapat meningkat, (2) pihak sekolah diharapkan meningkatkan dukungan kepada guru untuk meningkatkan kualitas pembelajaran sehingga dapat meningkatkan kesiapan belajar siswa dengan cara memberikan referensi ataupun pelatihan, dan (3) bagi peneliti yang akan meneliti variabel kesiapan belajar siswa, penelitian ini dapat dijadikan acuan dan referensi untuk mengembangkan penelitian yang membahas variabel kesiapan belajar siswa dikaitkan dengan variabel lain.

\section{DAFTAR PUSTAKA}

Bujuri, A. P., Pargito, \& Sudarmi. (2015). Pengaruh Motivasi Belajar dan Kesiapan Belajar terhadap Prestasi Belajar Geografi SMA Swadhipa. JPG (Jurnal Penelitian Geografi), $3(1)$.

Depdiknas. (2003). Undang-undang Republik Indonesia Nomor 20 Tahun 2003 Tentang Sistem Pendidikan Nasional. Jakarta: Depdiknas.

Fitriana, E. (2013). Hubungan antara Kesiapan Belajar dengan Hasil Belajar Matematika Warga Belajar Kelas XI Kelompok Belajar PAKET C SKB Bondowoso Semester Genap Tahun Pelajaran 2012-2013. Universitas Jember, Jember.

Riduwan. (2015). Belajar Mudah Penelitian untuk Guru-Karyawan dan Peneliti Pemula. Bandung: Alfabeta.

Sinta B, V. (2017). PENGARUH KESIAPAN BELAJAR TERHADAP HASIL BELAJAR MATA PELAJARAN EKONOMI KELAS $X$ DI SMA BINA JAYA PALEMBANG. UTILITY: Jurnal Ilmiah Pendidikan Dan Ekonomi, 1(1).

Sobur, A. (2013). Psikologi Umum. Bandung: Pustaka Setia.

Sundayana, R. (2015). Media dan Alat Peraga dalam Pembelajaran Matematika. Bandung: Alfabeta.

Susanto, A. (2016). Teori Belajar dan Pembelajaran: di Sekolah Dasar. Jakarta: Kencana.

Syahputra, M. R. (2016). Pengaruh Persiapan Belajar Siswa terhadap Prestasi Belajar Matematika pada Pokok Bahasan Kuadrat dan Akar Kuadrat Bilangan Bulat Siswa SMP Swasta Bandung Percut Sei Tuan. Jurnal Mantik Penusa, 19(1). 